\title{
Effect of Glutamine and Zinc containing Rehydration Electrolyte Solution on Serum Protein and Electrolytes in Cattle Calves having Acute Diarrhoea
}

\author{
Manu Jaiswal*, P.C. Shukla, Alok Mishra, Girjesh Upmanyu, Pratyush Kumar, \\ Mohammed Nazeer, Rajesh Bandre and Rupam Sinha
}

Faculty of Veterinary and Animal Science, Institute of Agricultural Sciences, Rajiv Gandhi South Campus, Banaras Hindu University, Barkachha, Mirzapur, (U.P.), India

*Corresponding author

\section{A B S T R A C T}

Keywords

Diarrhoeic cattle calf, Rehydration Electrolyte Solutions, Glutamine

Article Info

Accepted:

18 January 2019 Available Online: 10 February 2019
The present investigation was conducted on 24 diarrhoeic cattle calf (0-3 months old) and 08 healthy cattle calves. These diarrhoeic cattle calves were divided into three treatment groups (T1, T2, T3) and healthy control group (Tc) consisting of 08 cattle calves in each. Various Rehydration Electrolyte Solutions was prepared as RES1, RES2 and RES3 having zinc, glutamine and their combination respectively and effect of these RES solutions was seen on the alterations of serum protein and electrolytes on 0,3 and $7^{\text {th }}$ day. Serum total protein, albumin, globulin and albumin globulin ratio (A:G) was improved more significantly in T3 group in which RES3 was given also serum sodium, potassium and chloride were improved more significantly in T3 in which RES3 was administered.

\section{Introduction}

Calf diarrhoea is one of the most devastating diseases of the dairy industry worldwide (Elhassan et al., 2011 and Pourjafar et al., 2011).

Diarrhoea is defined as an increased frequency, fluidity or volume of faecal excretion. In diarrhoea, the clinicobiochemical alterations are complex in nature characterized by imbalance of fluid, electrolyte and acid base status (Radostits et al., 2010). Advances in our understanding of electrolyte losses and their replenishment through oral and intravenous route have greatly improved survival. The main aim of oral electrolyte therapy has been to maintain the patient by replacing fluid and electrolyte losses. World Health Organization (WHO) mentioned that oral rehydration therapy was one of the most significant advances in human medicine of twentieth century. Oral rehydration also continues to serve as the backbone of treatment protocols for diarrhoea in neonatal calves. 
Diarrhoea causes increase cost of treatment, weight loss, retarded growth or even significant mortalities of young. Etiology of diarrhoea is multiple, including infectious agents, poor management, reproductive factors, nutritional factors and immune status (Diaz-Lee et al., 2011). In diarrhoeic animals loose fluid, rapid dehydration, electrolyte loss and acidosis were seen. Though infectious agents may only cause initial damage to the intestine whereas death is usually results from dehydration, acidosis and loss of electrolytes

Some pathogens cause secretory diarrhoea, causing small intestinal enterocytes to switch from net absorption of fluid to net secretion of chloride, sodium and water into the intestinal lumen. Regardless of pathogens or the mechanism involved, diarrhoea increases the loss of electrolytes and water in the faces of calves and decrease milk intake. This process result in dehydration, strong ion acidosis, electrolyte abnormalities (decreased sodium and increase potassium), increase D-lactate concentration and a negative energy balance.

Advances in the understanding of intestinal physiology suggests that, it may be possible to reverse mucosal atrophy caused by enteritis. It has been proposed that glutamine which previously was thought to be non essential, is the limiting amino acid for mucosal regeneration. Ribeiro et al., (1994). The objective of the present study was to determine, if addition of glutamine to oral electrolyte solutions would speed mucosal regeneration, reduce weight loss and decrease the period of diarrhoea. Along with glutamine, zinc improved absorption of water and electrolytes by the intestine (Ghishan et al., 1984) regeneration of gut epithelium (Roy et al., 1992) increase levels of enterocyte brush border enzymes and enhances immunological mechanism for the clearance of infection. Supplementation of zinc improves immunity and may, hence, promote rapid clearance of diarrhoeal pathogens from the intestine.

\section{Materials and Methods}

The proposed work was conducted in the Department of Veterinary Medicine, Diagnostic lab, T.V.C.C. College of Veterinary Science and Animal Husbandry, Jabalpur, Instructional Livestock Farm Complex (ILFC) Adhartal and other private dairy farms/goshala near by Jabalpur, (M.P.).

For therapeutic study, a total of 24 acute diarrhoeic calves were randomly divided in to five treatment groups $\left(T_{1}, T_{2}\right.$ and $\left.T_{3}\right)$ whereas, in Tc, eight normal healthy calves have served as the control group (Table 1).

\section{Preparation of medicaments}

\section{Rehydration electrolyte solutions}

Rehydration Electrolyte Solutions (RES) were prepared fresh for every treatment group consisting of different chemical constituents and were used as oral rehydration therapy in acute diarrhoeic calves (Table 2).

\section{Blood serum for biochemical analyser}

A total of $7 \mathrm{ml}$ blood was collected from each animal in a sterilized glass at each of the specified intervals for serum biochemistry. Blood was allowed to coagulate by keeping the tubes in slants and serum was separated by spinning at $3000 \mathrm{rpm}$ for 10 minutes

\section{Sodium, Potassium and Chloride}

Sodium, Potassium and Chloride estimations were estimated using automatic electrolyte analyzer (Cornley Acculyte-3P Electrolyte Analyzer) and the values were expressed in $\mathrm{mEq} / \mathrm{L}$. 


\section{Total protein and fractions}

Total protein, albumin and globulin estimations were done using diagnostic reagent kits on blood chemistry Auto Analyser (model Erba Mannheim CHEM-5 plus v2). Ten $\mu$ l of serum was taken in eppendorf tube and admixed with $500 \mu 1$ total protein reagent for total protein estimation. Similarly, $5 \mu \mathrm{l}$ of serum was taken in eppendorf tube and admixed with $500 \mu \mathrm{l}$ albumin reagent for albumin estimation. Serum globulin $(\mathrm{g} / \mathrm{dl})$ was calculated by the subtraction of serum albumin concentration from the total serum protein concentration. The A:G ratio was deterimined by dividing the values of albumin with globulin.

\section{Statistical analysis}

The recorded data were analyzed as per the standard procedures outlined by Snedecor and Cochran (1994).

\section{Results and Discussion}

The mean value of total serum protein $(\mathrm{g} / \mathrm{dl})$ was decreased significantly on day 3 $\left(7.06^{\mathrm{ABab}} \pm 0.09\right)$ and day $7\left(7.06^{\mathrm{Bab}} \pm 0.09\right)$ post treatment as compared to day $0\left(7.61^{\mathrm{Aa}} \pm 0.11\right)$ pre treatment in group T3. In group T1 and T2 the mean value of total serum protein (g/dl) differed non significantly as compared to healthy control (Table 3). The higher mean values of total serum protein, compared to the healthy control group on day 0 pre treatment also reported by Singh et al., (2014) and Gupta et al., (2016). This might have highlighted the potentially hazardous clinical status of acute tissue dehydration. In contrast, Tikko et al., (2017) have reported non significant increase in mean total protein and albumin value in all the three groups.

The mean value of serum albumin $(\mathrm{g} / \mathrm{dl})$ was decreased significantly on day 3
$\left(3.53^{\mathrm{ABa}} \pm 0.03\right)$ and day $7\left(3.44^{\mathrm{Ba}} \pm 0.03\right)$ post treatment as compared to day $0\left(3.64^{\mathrm{Aa}} \pm 0.04\right)$ pre treatment in group T3. In group T1 and $\mathrm{T} 2$ the mean value of total serum albumin $(\mathrm{g} / \mathrm{dl})$ decreased non significantly as compared to healthy control (Table 4). The results of the study indicated significant decrease in the mean value of serum albumin and serum globulin on day 3 and 7 post treatment as compared to day 0 pre treatments in group T3. As also reported by Gupta (2015) that mean serum globulin concentration in diarrhoeic cattle calves were significantly decreased $(\mathrm{p}<0.05)$ whereas significantly higher serum albumin concentration in diarrhoeic buffalo calves was reported by (Gupta, 2016). Increased albumin and globulin concentration was also reported by Mir (2009), the increase in the Globulin concentration might be due to activation of hummoral immunity in infection (Satyanarayana, 2005 and Tikko et al., 2017) However, Bednarski et al., (2015) observed notably low concentration $(\mathrm{g} / \mathrm{dl})$ of serum albumin (1.54) in diarrhoeic calves on 14-21 day post partum.

The mean value of serum globulin $(\mathrm{g} / \mathrm{dl})$ was decreased significantly on day 3 $\left(3.79^{\mathrm{AB}} \pm 0.06\right)$ and day $7\left(3.60^{\mathrm{B}} \pm 0.07\right)$ post treatment as compared to day $0\left(3.97^{\mathrm{A}} \pm 0.07\right)$ pre treatment in group T5. In group T1 and $\mathrm{T} 2$ the mean value of total serum globulin $(\mathrm{g} / \mathrm{dl})$ decreased non significantly as compared to healthy control (Table 5).

The mean value of serum sodium $(\mathrm{mEq} / \mathrm{L})$ was increased significantly in group T5 on day $3 \quad\left(132.61^{\mathrm{Ab}} \pm 1.07\right)$ and day 7 $\left(134.79^{\mathrm{Ab}} \pm 0.81\right)$ post treatment respectively as compared to day $0\left(129.46^{\mathrm{Bb}} \pm 1.20\right)$ pre treatment. On the other hand, there was no significant increase in mean value of serum sodium as recorded in group $\mathrm{T} 2$ and $\mathrm{T} 3$ on day 3 and day 7 post treatment (Table 6). The plasma sodium concentration showed a 
significant $(p<0.05)$ decrease in neonatal diarrhoeic calves at pre treatment in the group indicating hyponatremia which simulated with the observations of Pal and Pachauri (2010) and Tikko et al., (2017). Further dehydrated neonatal ruminants were found to be typically hyponatremic as reported by Guzelbektes et al., (2006). Hyponatremia in diarrhoeic calves is reported to be apparently the consequence of accelerated transfer of sodium along with water into intestinal lumen (Malik et al., 2013 and Gupta et al., 2016)

The mean value of serum potassium $(\mathrm{mEq} / \mathrm{L})$ was decreased significantly in group $\mathrm{T} 5$ on day $3\left(6.30^{\mathrm{Bb}} \pm 1.65\right)$ and day $5\left(4.99^{\mathrm{Cb}} \pm 0.11\right)$ post treatment as compared to day 0 $\left(8.48^{\mathrm{Ab}} \pm 1.65\right)$ pre treatment also there was significant decreased on day $7\left(5.24^{\mathrm{Bb}} \pm 0.45\right)$ post treatment as compared to day 0 $\left(8.09^{\mathrm{Ab}} \pm 1.35\right)$ pre treatment.

On the other hand, there was no significant decrease in mean value of serum potassium as recorded in group T2 and T3 on day 3 and day 7 post treatment as compared to healty control (Table 7). The significant $(p<0.05)$ increase in plasma potassium concentration in neonatal diarrhoeic calves at pre treatment indicting hyperkalemia, that may be attributed to the metabolic acidosis which might have induced the translocation of $\mathrm{K}^{+}$from the intracellular to extracellular compartment, thus raising the plasma $\mathrm{K}^{+}$concentration where as Kerr (1989) have indicated that in severely dehydrated diarrhoeic calves hyperkalemia resulted due to serious decrease in renal perfusion leading to failure of $\mathrm{K}^{+}$ excretion. Hyperkalemia in diarrhoeic calves could be attributed to increased renal tubular reabsorption of potassium in response to acidosis and also oligourea or anuria in which kidney failed to eliminate excess potassium (Wakwe and Okon, 1995). Besides these, Fisher et al., (1971) has mentioned the cause of hyperkalemia as increased potassium retention by kidney and due to cellular damage. Whereas, Radostits et al., (2010) reported that the increased calf mortality could be due to of cardiac arrhythmia.

The mean value of serum chloride $(\mathrm{mEq} / \mathrm{L})$ was found to be significantly higher in group T5 comparably on day $3\left(93.59^{\mathrm{Bb}} \pm 0.51\right)$ and day $7 \quad\left(95.18^{\mathrm{Ab}} \pm 0.39\right) \quad$ post treatment respectively as compared to day 0 $\left(91.93^{\mathrm{Cb}} \pm 0.44\right)$ pre treatment. But on the other hand, there was no significant decrease in group T2 and T3 as compared to healthy control (Table 8). Similar observations were also noted by Tikko et al., (2017). During the diarrhoea the loss of chloride ions in the secretion of the intestinal fluids leads to hypochloremia in diarrhoeic calves (Radostits et al., 2010).

Table.1 Experimental design for therapeutic study

\begin{tabular}{|c|c|l|}
\hline Groups & No. of animals & Treatment \\
\hline $\mathbf{T}_{\mathbf{c}}$ & 8 & Healthy control \\
\hline $\mathbf{T}_{\mathbf{1}}$ & 8 & Rehydration Electrolyte Solution (RES 1) \\
\hline $\mathbf{T}_{\mathbf{2}}$ & 8 & Rehydration Electrolyte Solution (RES 2) \\
\hline $\mathbf{T}_{\mathbf{3}}$ & 8 & Rehydration Electrolyte Solution (RES 3) \\
\hline
\end{tabular}

- In Tc (Control) group standard ORS (WHO-2002) was given as per recommendation.

- The acute diarrhoeic calves of all the groups (T1-T3) were treated with medicines which included; Ofloxacin and Ornidazole @ 20mg /kg b.w. I/V for 3 days and Fenbendazole @ 7.5mg/kg b.w. PO.

- RES was used @ 60 to $150 \mathrm{ml} / \mathrm{kg}$ b.w./day PO, daily for 5 days depending upon the severity of the diarrhoea (Radostits et al., 2010). 
Table.2 Composition of rehydration electrolyte solutions used in acute diarrhoeic calves

\begin{tabular}{|l|l|}
\hline RES & \multicolumn{1}{c|}{ CONSTITUENTS } \\
\hline RES1 & $\begin{array}{l}\text { Sodium Chloride, Sodium bicarbonate, Potassium chloride, Table sugar, } \\
\text { Zinc }\end{array}$ \\
\hline RES2 & $\begin{array}{l}\text { Sodium Chloride, Sodium bicarbonate, Potassium chloride, Glutamine } \\
\text { RES3 }\end{array}$ \\
$\begin{array}{l}\text { Sodium Chloride, Sodium bicarbonate, Potassium chloride, Glutamine, } \\
\text { Zinc }\end{array}$ \\
\hline
\end{tabular}

*These were prepared by dissolving the contents in one litre of water in each case.

Table.3 Serum total protein $(\mathrm{g} / \mathrm{dl})$ of diarrhoeic calves in different treatment groups at different intervals

\begin{tabular}{|c|c|c|c|}
\hline \multirow{2}{*}{ Groups } & \multicolumn{3}{|c|}{ Treatment intervals (Day) } \\
\cline { 2 - 4 } & 0 days & 3 days & 7 days \\
\hline Tc & $6.45^{\mathrm{b}} \pm 0.60$ & $6.45^{\mathrm{b}} \pm 0.60$ & $6.47^{\mathrm{b}} \pm 0.60$ \\
\hline T1 & $7.64^{\mathrm{a}} \pm 0.07$ & $7.54^{\mathrm{a}} \pm 0.05$ & $7.41^{\mathrm{a}} \pm 0.06$ \\
\hline T2 & $7.56^{\mathrm{a}} \pm 0.11$ & $7.56^{\mathrm{a}} \pm 0.11$ & $7.42^{\mathrm{a}} \pm 0.12$ \\
\hline T3 & $7.61^{\mathrm{Aa}} \pm 0.11$ & $7.33^{\mathrm{ABab}} \pm 0.09$ & $7.06^{\mathrm{Bab}} \pm 0.09$ \\
\hline
\end{tabular}

Mean values with superscript between treatment (lowercase) and between interval (uppercase) differ significantly ( $\mathrm{p}$ $<0.05)$.

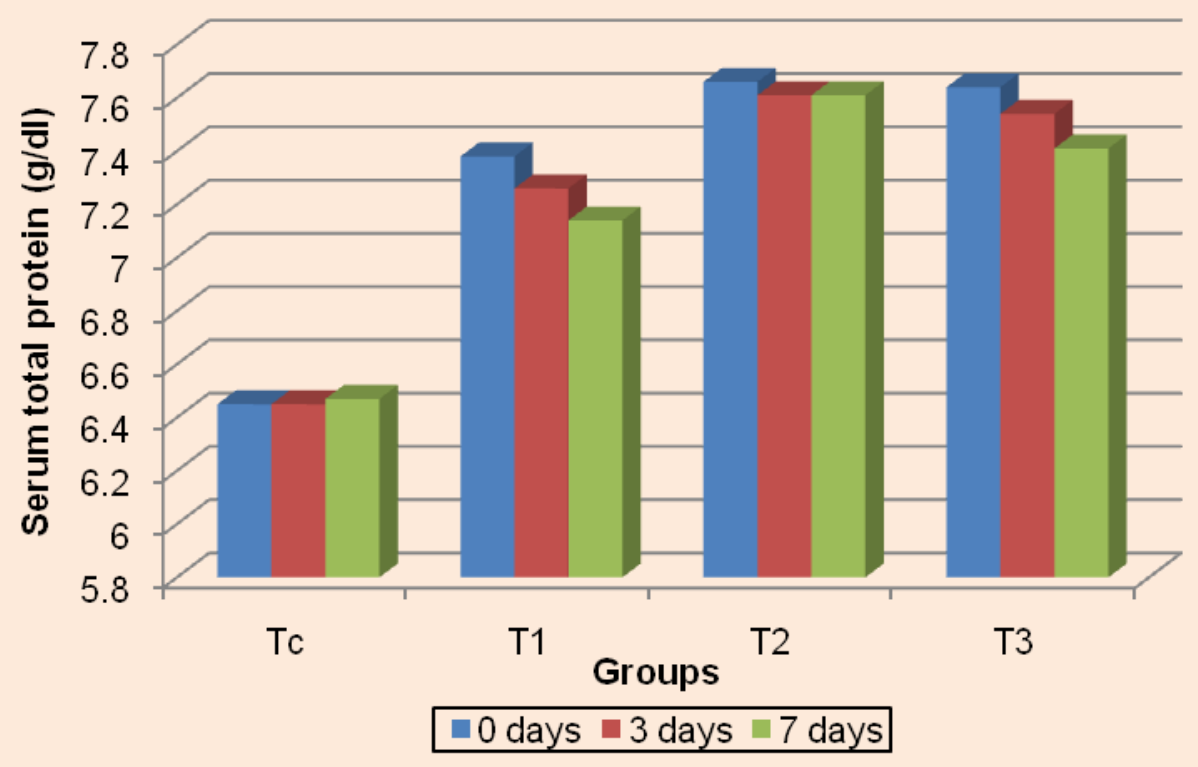


Table.4 Serum albumin $(\mathrm{g} / \mathrm{dl})$ of diarrhoeic calves in different treatment groups at different intervals

\begin{tabular}{|c|c|c|c|}
\hline \multirow{2}{*}{ Groups } & \multicolumn{3}{|c|}{ Treatment intervals (Day) } \\
\cline { 2 - 4 } & 0 days & 3 days & 7 days \\
\hline Tc & $2.80^{\mathrm{b}} \pm 0.22$ & $2.75^{\mathrm{b}} \pm 0.16$ & $2.78^{\mathrm{b}} \pm 0.16$ \\
\hline T1 & $3.66^{\mathrm{a}} \pm 0.05$ & $3.65^{\mathrm{a}} \pm 0.05$ & $3.64^{\mathrm{a}} \pm 0.05$ \\
\hline T2 & $3.80^{\mathrm{a}} \pm 0.090$ & $3.54^{\mathrm{a}} \pm 0.08$ & $3.55^{\mathrm{a}} \pm 0.10$ \\
\hline T3 & $3.64^{\mathrm{Aa}} \pm 0.04$ & $3.53^{\mathrm{ABa}} \pm 0.03$ & $3.44^{\mathrm{Ba}} \pm 0.03$ \\
\hline
\end{tabular}

Mean values with superscript between treatment (lowercase) and between interval (uppercase) differ significantly ( $p$ $<0.05)$.

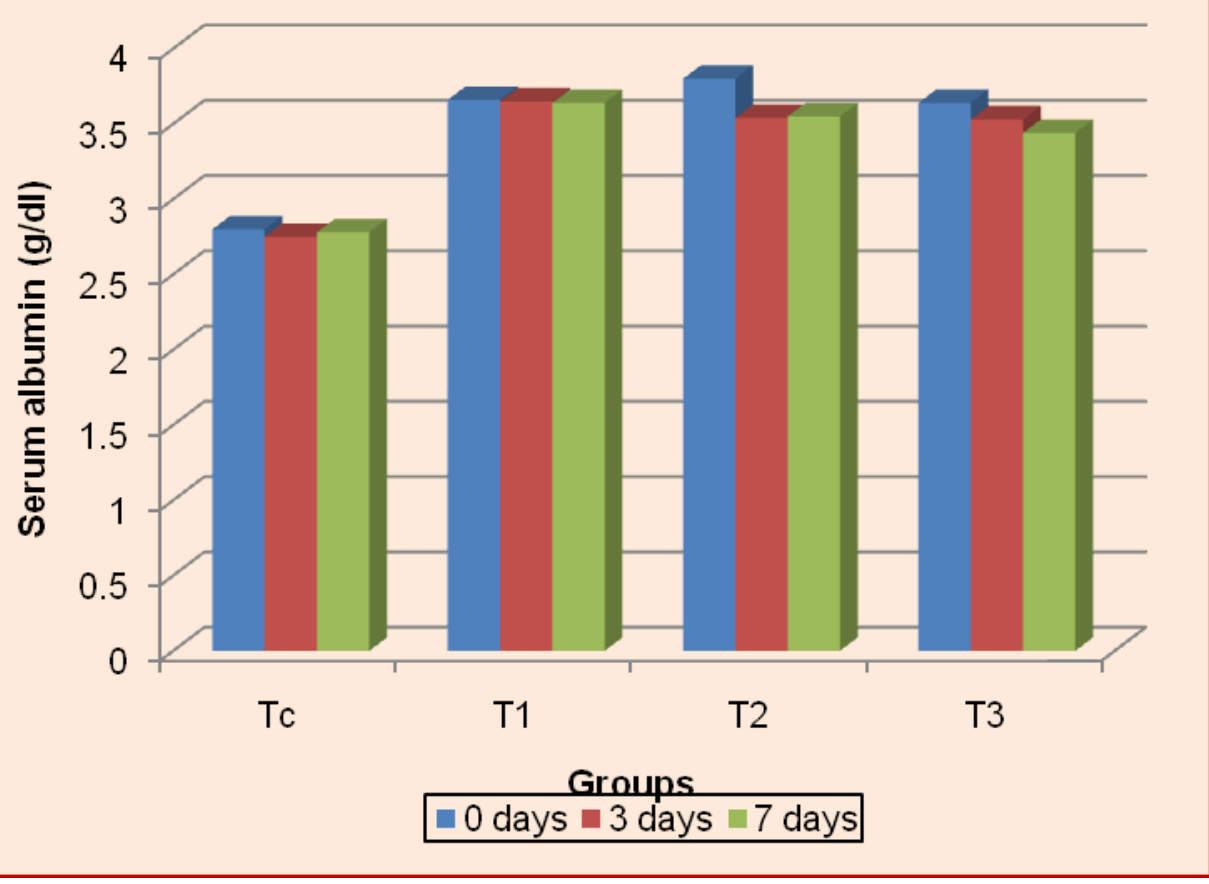

Table.5 Serum globulin $(\mathrm{g} / \mathrm{dl})$ of diarrhoeic calves in different treatment groups at different intervals

\begin{tabular}{|c|c|c|c|}
\hline \multirow{2}{*}{ Groups } & \multicolumn{3}{|c|}{ Treatment intervals (Day) } \\
\cline { 2 - 4 } & 0 days & 3 days & 7 days \\
\hline Tc & $3.65 \pm 0.54$ & $3.70 \pm 0.53$ & $3.68 \pm 0.54$ \\
\hline T1 & $3.98 \pm 0.08$ & $3.89 \pm 0.05$ & $3.76 \pm 0.03$ \\
\hline T2 & $3.75 \pm 0.13$ & $4.01 \pm 0.16$ & $3.86 \pm 0.13$ \\
\hline T3 & $3.97^{\mathrm{A}} \pm 0.07$ & $3.79^{\mathrm{AB}} \pm 0.06$ & $3.60^{\mathrm{B}} \pm 0.07$ \\
\hline
\end{tabular}

Mean values with superscript between treatment (lowercase) and between interval (uppercase) differ significantly ( $\mathrm{p}$ $<0.05)$. 


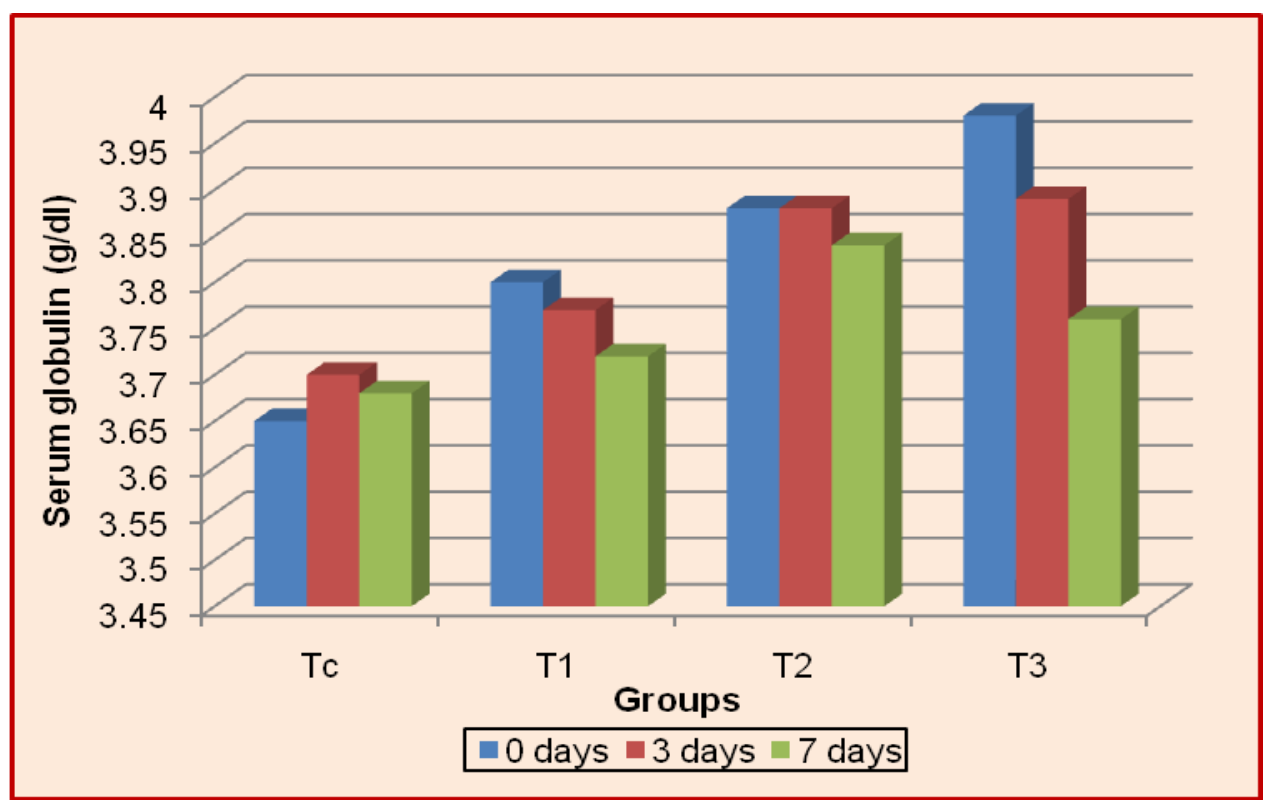

Table.6 Serum sodium $(\mathrm{mEq} / \mathrm{L})$ of diarrhoeic calves in different treatment groups at different intervals

\begin{tabular}{|c|c|c|c|}
\hline \multirow{2}{*}{ Groups } & \multicolumn{3}{|c|}{ Treatment intervals (Day) } \\
\cline { 2 - 4 } & 0 days & 3 days & 7 days \\
\hline Tc & $145.03^{\mathrm{a}} \pm 1.73$ & $144.37^{\mathrm{a}} \pm 1.47$ & $145.46^{\mathrm{a}} \pm 1.52$ \\
\hline T1 & $131.09^{\mathrm{b}} \pm 0.35$ & $131.16^{\mathrm{b}} \pm 0.35$ & $131.53^{\mathrm{c}^{\circ} \pm 0.25}$ \\
\hline T2 & $130.76^{\mathrm{b}} \pm 0.37$ & $131.57^{\mathrm{b}} \pm 0.39$ & $132.08^{\mathrm{c}} \pm 0.44$ \\
\hline T3 & $129.46^{\mathrm{Bb}} \pm 1.20$ & $132.61^{\mathrm{Ab}} \pm 1.07$ & $134.79^{\mathrm{Ab}} \pm 0.81$ \\
\hline
\end{tabular}

Mean values with superscript between treatment (lowercase) and between interval (uppercase) differ significantly (p $<0.05)$.

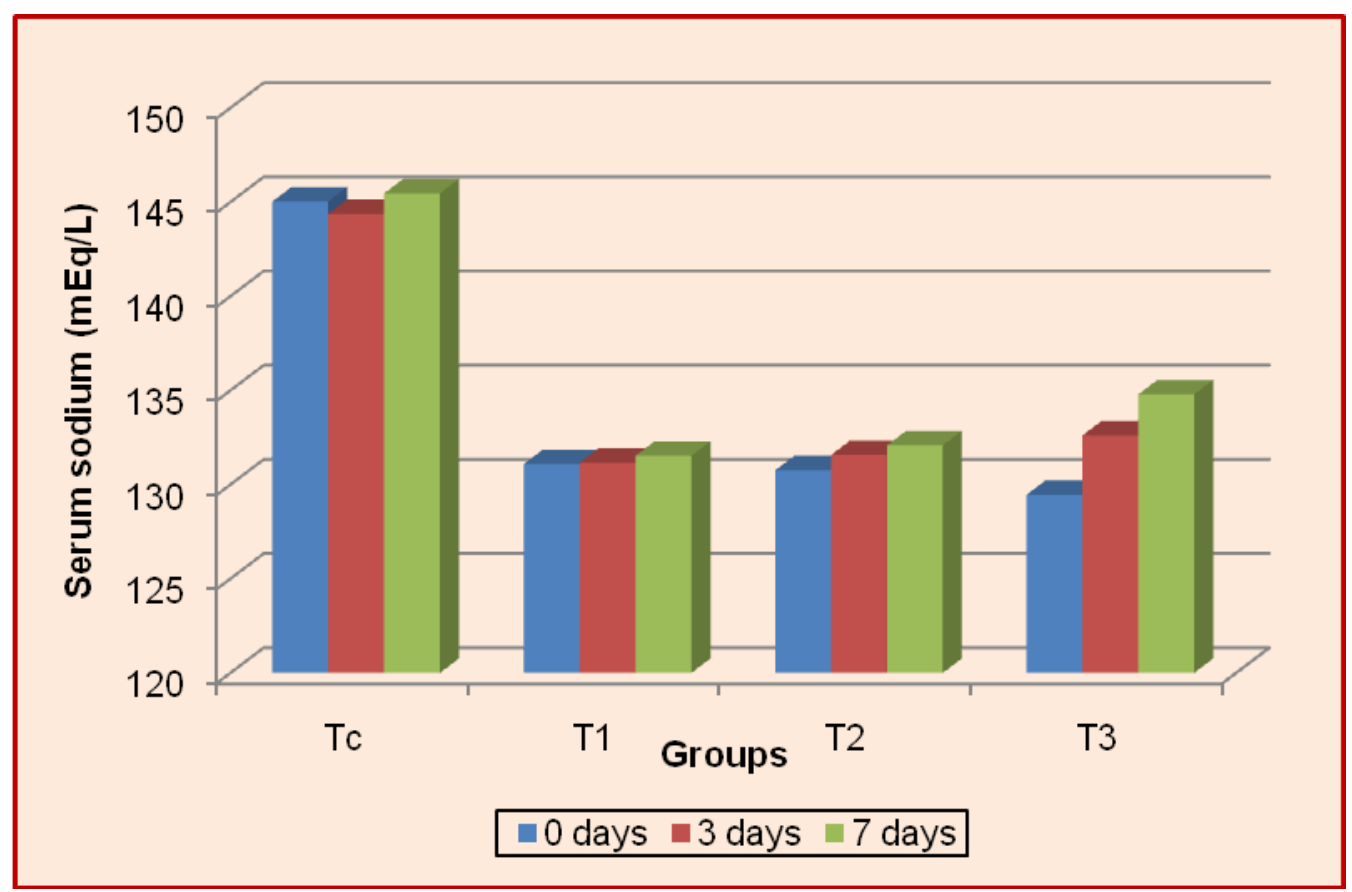


Table.7 Serum potassium $(\mathrm{mEq} / \mathrm{L})$ of diarrhoeic calves in different treatment groups at different intervals

\begin{tabular}{|c|c|c|c|}
\hline \multirow{2}{*}{ Groups } & \multicolumn{3}{|c|}{ Treatment intervals (Day) } \\
\cline { 2 - 4 } & 0 days & 3 days & 7 days \\
\hline Tc & $4.27^{\mathrm{b}} \pm 0.24$ & $4.30^{\mathrm{b}} \pm 0.73$ & $4.59^{\mathrm{b}} \pm 0.22$ \\
\hline T1 & $5.58^{\mathrm{b}} \pm 0.11$ & $5.31^{\mathrm{b}} \pm 0.12$ & $5.15^{\mathrm{b}} \pm 0.11$ \\
\hline T2 & $5.57^{\mathrm{Ab}} \pm 0.09$ & $5.26^{\mathrm{Ab}} \pm 0.10$ & $5.14^{\mathrm{Ab}} \pm 0.09$ \\
\hline T3 & $5.62^{\mathrm{A}} \pm 0.08$ & $5.13^{\mathrm{Bb}} \pm 0.73$ & $4.99^{\mathrm{Bb}} \pm 0.07$ \\
\hline
\end{tabular}

Mean values with superscript between treatment (lowercase) and between interval (uppercase) differ significantly (p $<0.05)$.

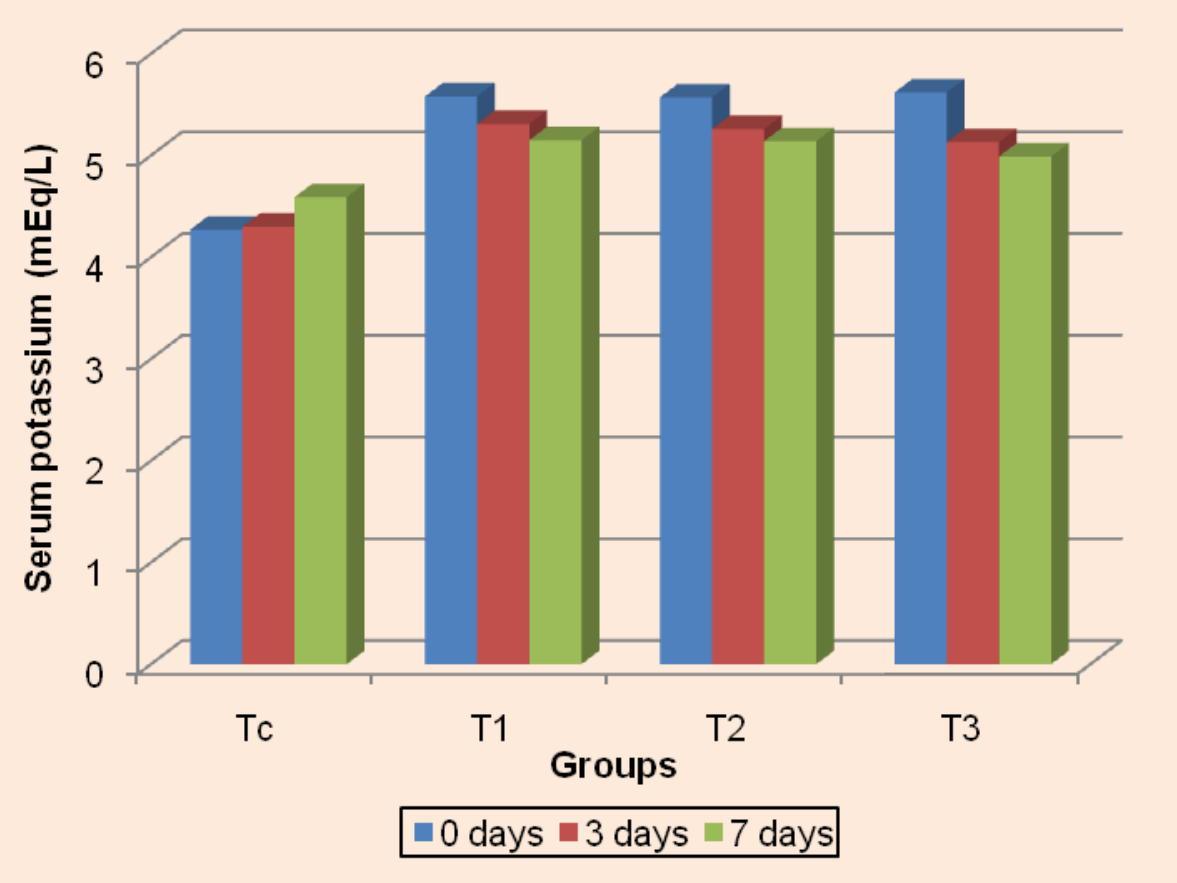

Table.8 Serum chloride $(\mathrm{mEq} / \mathrm{L})$ of diarrhoeic calves in different treatment groups at different intervals

\begin{tabular}{|c|c|c|c|}
\hline \multirow{2}{*}{ Groups } & \multicolumn{3}{|c|}{ Treatment intervals (Day) } \\
\cline { 2 - 4 } & 0 days & 3 days & 7 days \\
\hline Tc & $98.57^{\mathrm{a}} \pm 1.55$ & $98.89^{\mathrm{a}} \pm 1.56$ & $98.87^{\mathrm{a}} \pm 1.51$ \\
\hline T1 & $93.13^{\mathrm{b}} \pm 0.75$ & $93.26^{\mathrm{b}} \pm 0.73$ & $93.31^{\mathrm{b}} \pm 0.76$ \\
\hline T2 & $93.29^{\mathrm{b}} \pm 0.69$ & $93.49^{\mathrm{b}} \pm 0.67$ & $93.67^{\mathrm{b}} \pm 0.64$ \\
\hline T3 & $91.93^{\mathrm{Cb}} \pm 0.44$ & $93.59^{\mathrm{Bb}} \pm 0.51$ & $95.18^{\mathrm{Ab}} \pm 0.39$ \\
\hline
\end{tabular}

Mean values with superscript between treatment (lowercase) and between interval (uppercase) differ significantly ( $p$ $<0.05)$. 


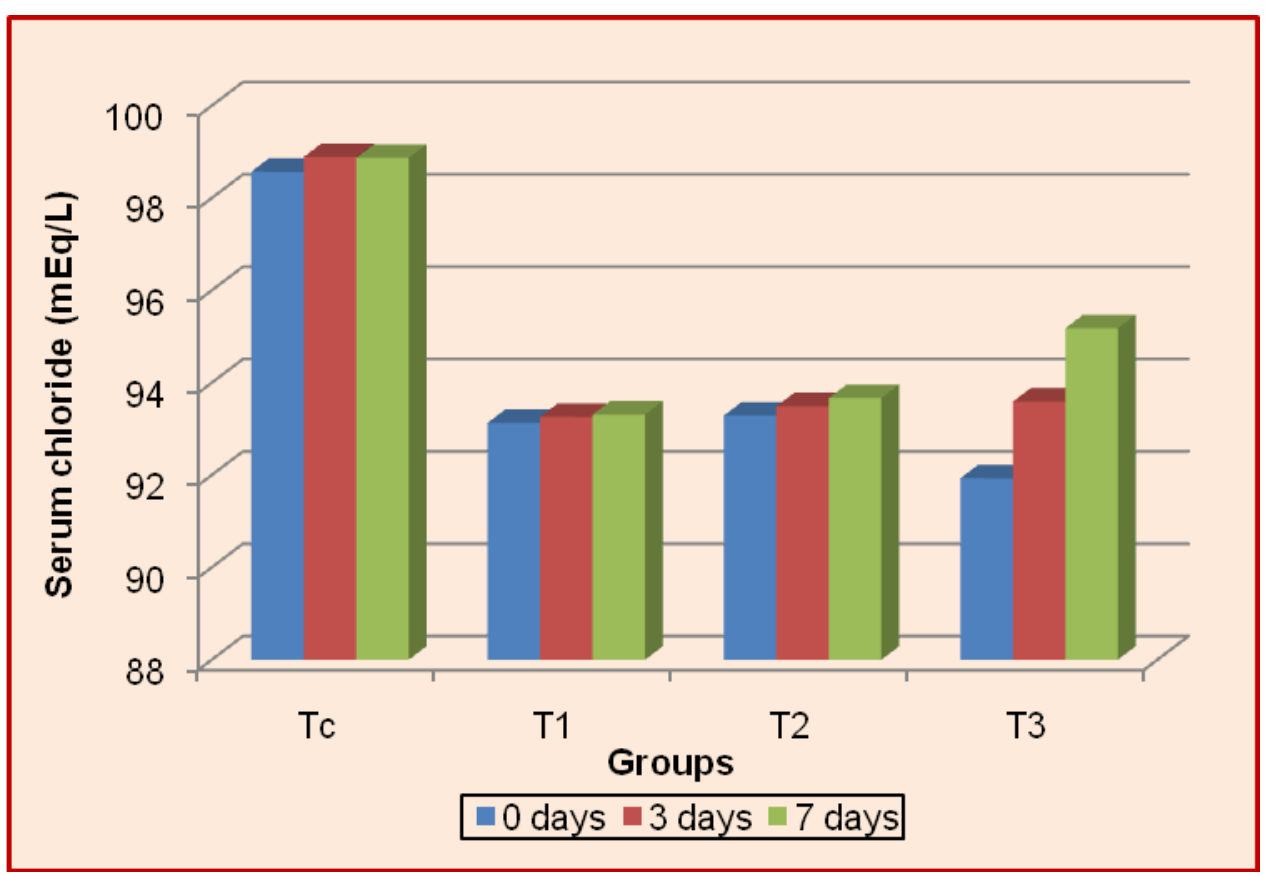

Glutamine is the fundamental respiratory fuel for the small intestine and has been classified as a conditional essential amino acid and supplementation of glutamine has been shown to cause marked improvement in gastrointestinal structure and function after injury. Glutamine is able to function as a sodium co transport substrate in an electrogenic manner and to stimulate electroneutral sodium chloride absorption, it also help in reduce weight loss and decrease the period of diarrhoea (Naylor et al., 1997) and promote the absorption of sodium and water even more effective than glucose.

Zinc reduces the duration and severity of acute diarrhoea also improved absorption of water and electrolyte by the intestine, regeneration of gut epithelium, increase levels of entrocyte brush border enzymes and enhance immunological mechanism for the clearance of infection.

Citrate is common bicarbonate precursor that is used in ORT because bicarbonate itself would react with the acid in the abomasums to produce $\mathrm{CO}_{2}$. Sodium Bicarbonate is act as an alkaniser which reverse the metabolic acidosis. Prevention is still the best approach to reduce occurrence of diarrhoea and avoid unnecessary use of drugs. Monitoring and early diagnostics and treatment of diarrhoea in calves is a key point to improve outcomes. Targeted use of antibiotics for treatment of diarrhoea can reduce expenses with drug treatment, reduce length of disease and decrease the risk of selecting multidrug resistant bacteria.

In conclusion, the overall results obtained under the present investigations have concluded that the therapeutic regimen adopted in the treatment of acute diarrhoeic calves under groups T3 in which RES-3 (Sodium Chloride, Sodium bicarbonate, Potassium chloride, Glutamine, Zinc) was given found to be most efficacious as evident by the improvement in terms of improved serum protein fraction and serum electrolyte.

\section{Acknowledgement}

The authors are thankful to the Dean, College of Veterinary Sciences and Animal Husbandry and Hon'ble Vice Chancellor of the University for providing all the facilities 
to conduct the study. The assistance of all the hospital staffs including TVCC, is highly acknowledged.

\section{References}

Bednarski, M., Kupczynski, R. and Sobiech, P. (2015). Acid-base disorders in calves with chronic diarrhoea. Polish Journal of Veterinary Science, 18: 207-215.

Diaz-Lee, A., Mercado, R.E.O., Onuaha, L.S., Ozaki, P., Munoz, F.J., Martinez and Fredes, F. (2011). Cryptosporidium parvum in diarrheic lambs detected by microscopy and identified by immunochromatographic and molecular methods. Veterinary Parasitology, 167: 139-144.

Elhassan, A.M., Fadol, M.A. and El-Hussein, A.M. (2011). Seroprevalence of bovine herpes virus-1, bovine herpes virus-4 and bovine viral diarrhea virus in dairy cattle in Sudan. Pakistan Veterinary Journal, 31: 317-320.

Fisher, E.W. and Dela, F.G.H. (1971). Water and electrolyte studies in new born calves with particular reference to the effect of diarrhoea. Research in Veterinary Science, 13: 315-322.

Ghishan, F.K. 1984. Transport of electrolytes, water, and glucose in zinc deficiency. $J$ Pediatr Gastroenterol Nutr., 3: 608-12.

Gupta, P. (2015). Efficacy of Psidium Guajava (Guava) leaves as an antidiarrhoeal in calves with special reference to E. coli. M.V.Sc. \& A.H., Thesis (Veterinary Medicine) Nanaji Deshmukh Veterinary Science University, Jabalpur.

Gupta, R. (2016). Therapeutic efficacy of herbal formulations in diarrhoeic calves. M.V.Sc. thesis (Veterinary Medicine), Nanaji Deshmukh Veterinary Science University, Jabalpur.

Guzelbektes, H., Coskun, A. and Sen, I. (2006). Relationship between the degree of dehydration and the balance of acidbased changes in dehydrated calves with diarrhoea. Bulletin of the Veterinary Institute in Pulawy, 51: 83-87.

Kerr, M.G. (1989). Veterinary Laboratory Medicine: Clinical biochemistry and haematology, Blackwell Scientific Publications, London.

Malik, S., Kumar, A., Verma, K.A., Gupta, K.M., Sharma, D.S., Sharma, K.A. and Rahal, A. (2013). Haematological profile and chemistry in diarrhoeic calves affected with Colibacillosis. Journal of Animal Health and Production, 1: 10-14.

Mir, N. (2009). Rehydration and herbal therapy in calf diarrhoea. M.V.Sc. \& A.H., Thesis (Veterinary Medicine) Jawaharlal Nehru Krishi Vishwa Vidyalaya, Jabalpur.

Naylor, J.M., Petrie, L., Rodriguez, M.I. and Skilnick, P.A. (1997). Comparison of oral electrolyte solutions in diarrheic calves. Canadian Veterinary Journal, 31: 753-760.

Pal, B. and Pachauri, S.P. (2008). Effect of oral rehydration in neonatal calves treated for diarrhoea induced with E.coli (0101:K99) infection. Indian Journal Veterinary Research, 17:19-26.

Pourjafar, M., Badiei, K., Nadalian, M.G. and Jafari, J.R. (2011). Effect of long term administration of frozen and fermented colostrum of vaccinated cows on performance and prevention of neonatal calf diarrhea. Pakistan Veterinary Journal, 31: 199-202.

Radostits, O.M., Gay, C.C Blood, D.C. and Hinchcliff, K.W. (2010). Disease of the alimentary tract. A Textbook of Disease of Cattle, Sheep, Pigs, Goats and Horses. $10^{\text {th }}$ Edn., Saunders publication co., Oxford, London, pp 99-100.

Ribeiro, H.Jr., Ribeiro, T., Mattos, A., Palmeira, C., Fernandez, D. and 
Sant'Ana, I. 1994. Treatment of acute diarrhea with oral rehydration solutions containing glutamine. J Am Coll Nutr., 13: 251-5.

Roy, S.K., Behrens, R.H., Haider, R., Akramuzzaman, S.M., Mahalanabis, D. and Wahed, M.A. 1992. Impact of zinc supplementation on intestinal permeability in Bangladeshi children with acute diarrhoea and persistent diarrhoea syndrome. $J$ Pediatr Gastroenterol Nutr., 15: 289-96.

Satyanarayana, U. (2005) Biochemistry. $2^{\text {nd }}$

Ed. Books and Allied (P) Ltd. pp.189

Singh, M. Gupta, K.V., Mandal, B.D., Bansal, K.S., Sharma, K.D., Shakya, M. and Gopinath, D. (2014). A study on alteration in Haematological parameter in colibacillosis affected calves. International Journal of Advanced
Research, 2: 746-750.

Snedecor, G.W. and Cochran, W.G. (1994). Statistical Mehods. $8^{\text {th }}$ Edn., The IOWA State University Press, USA.

Tikoo, A., Soodan, J.S., Singh, G. and Singh, I. (2017). Effect of various therapeutic regimens on the treatment of calf diarrhea and their effect on various clinico, hematobiochemical parameters. International Journal of Livestock Research, 7: 174-183.

Wakwe, V.C. and Okon, K.O. (1995). Plasma electrolyte pattern of calf with protein energy malnutrition and calf with prolonged diarrhea. Journal of Tropical Pediatrics, 41: 59-60.

WHO.(2002). WHO drug information http://apps.who.int/medicine does/en/d/Js4950e/2.4html

\section{How to cite this article:}

Manu Jaiswal, P.C. Shukla, Alok Mishra, Girjesh Upmanyu, Pratyush Kumar, Mohammed Nazeer, Rajesh Bandre and Rupam Sinha. 2019. Effect of Glutamine and Zinc containing Rehydration Electrolyte Solution on Serum Protein and Electrolytes in Cattle Calves having Acute Diarrhoea. Int.J.Curr.Microbiol.App.Sci. 8(02): 2165-2175. doi: https://doi.org/10.20546/ijcmas.2019.802.251 